\title{
Is the adjective distinct from the noun as a grammatical category in biblical Hebrew?
}

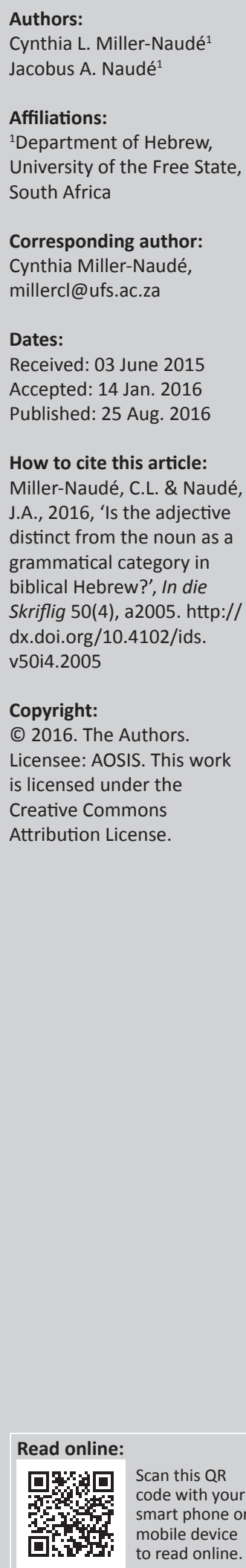

The adjective is a beleaguered category in biblical Hebrew grammar with many grammars of biblical Hebrew denying that the adjective is a category distinct from substantives. Within a variety of linguistic theories, the status of the adjective as a grammatical category is also debated. Cross-linguistically adjectives exhibit extraordinary variety: in some languages showing similarities to nouns, in others to verbs and in still others to both nouns and verbs. The debate concerning the status of the adjective is mirrored by the broader debate within contemporary linguistics concerning how the issue of grammatical categorisation ought to be approached. In this article, we re-examine the question of whether or not the adjective is a distinct grammatical category from the noun in biblical Hebrew. We approach the question of the status of the adjective as a grammatical category from two perspectives: morphology and syntax.

\section{Introduction}

The adjective is a beleaguered category in biblical Hebrew grammar. Many grammars of biblical Hebrew deny that the adjective is a category distinct from substantives. Joüon and Muraoka (2009:217) are representative of this viewpoint: 'The noun in Hebrew and Semitic grammar includes not only the substantive but also the adjective, for in its formation and inflection the adjective does not differ from the substantive'. Similarly, Waltke and O'Connor (1990), following Richter $(1978 ; 1979 ; 1980)$, see a grammatical category 'nomen' which is comprised of substantives, adjectives and numerals. This judgement concerning the lumping of the adjective with the noun relies upon the morphological shape of the adjective. As Gesenius' (Gesenius, Kautzsch \& Cowley 1910:§79a) grammar notes, 'the adjective agrees in form entirely with the substantive'.

Andersen and Forbes (2012:31) agree that the adjective is a sub-category of the noun, but take a unique approach in two respects. Firstly, they restrict the definition by requiring 'that any adjective modify an immediately preceding substantive'. Sentences such as (1) are excluded:

\section{1 Samuel 19:4}

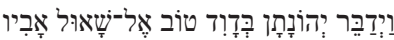

'Jonathan spoke concerning David good to Saul his father'.

Secondly, Andersen and Forbes (2012:31) are more expansive than other scholars in including within the category of adjectives demonstrative pronouns and free pronouns, 'if they are definite and if they modify an immediately preceding substantive'. Phrases in which the demonstrative pronoun modifies an immediately preceding noun would qualify it for adjective status, as illustrated in (2):

\section{Genesis 15:7}

הָאָרץ הַזּאת

'this land'

Within a variety of linguistic theories, the status of the adjective as a grammatical category is problematic. For example within the Government and Binding approach to generative grammar, Chomsky (1981:48) viewed grammatical categories as composed of two features: substantives $[+\mathrm{N}]$, including nouns and adjectives, and predicates $[+\mathrm{V}]$, including verbs and adjectives. The combination of these two features results in nouns [+ N, -V], verbs [-N, + V], adjectives [+ N, + V] and adpositions (i.e. prepositions and postpositions) $[-\mathrm{N},-\mathrm{V}]$. Another generative approach to

Note: It is our pleasure to dedicate this article to our good friend and colleague, Prof. Paul Kruger, on the occasion of his retirement from North-West University with gratitude for his scholarship and friendship. We thank our colleague, Dr Tania Notarius, for her comments on an earlier version of this article. We also thank our research assistant, Ms Jacqueline Smith, for her assistance in collecting the data for this research. This work is based on research supported in part by the National Research Foundation of South Africa (Cynthia L. MillerNaudé UID 95926 \& Jacobus A. Naudé UID 85902). The grantholders acknowledge that opinions, findings and conclusions or recommendations expressed in any publication generated by the NRF supported research are those of the authors, and that the NRF accepts no liability whatsoever in this regard. 
lexical categories is taken by Jackendoff (1977) in which the relevant features are [Subject] and [Object]. Nouns are then [+ Subject, -Object], verbs are [+ Subject, + Object], adjectives are [-Subject, -Object] and adpositions are [-Subject, + Object] (see the discussion in Baker 2003:11-12). In both approaches to categories, the adjective has a secondary status with respect to nouns and verbs. However, lexical categories and their features did not play a substantial role in these varieties of generative grammar.

Functional grammarians have described lexical categories on the basis of semantic and/or pragmatic distinctions (cf. Baker 2003:14-15). Some functionalists have described lexical categories on the basis of the kinds of items that they refer to, especially within discourse (e.g. Givón 1984; Hopper \& Thompson 1984) - nouns denote things (long-term states of affairs) or 'discourse-manipulable participants', verbs denote events (dynamic, short-term states of affairs), adjectives denote states or properties (medium-length states of affairs). Other functionalists have described lexical categories on the basis of the prototypical functions of communication (e.g. Hengeveld 1992) - nouns refer, verbs predicate, adjectives modify. The cognitive linguistics perspective is related to the functional one in identifying prototypical semantic properties of the lexical categories. Croft (1991:65), for example, views the prototypical lexical classes as 'objects', 'actions' and 'properties' in the place of the traditional categories of nouns, verbs and adjectives, respectively. These categories have complexes of features, which he identifies as valency, stativity, persistence and gradability. Properties, for example have a valence of 1 , describe states and those states are persistent and gradable. Objects, by contrast, have a valence of 0 , describe states, and are persistent but not gradable. To take another example, Taylor (2003:343-344) discusses the 'modification of nominals and noun phrases' as involving four possible sorts on the basis of semantics: specification (of the type), instantiation (of the token from its type), quantification (of the token) and grounding (i.e. the location of the designated instance within the speech event). Functional and cognitive perspectives, like generative approaches, view adjectives as secondary to nouns and verbs. This is especially clear in the work of the functional grammarian Hengeveld (1992), who views categories as variable - a single lexical item in a particular language might therefore be both a noun and an adjective, both an adjective and an adverb, or both a verb and an adjective.

The difficulty in determining an appropriate basis for lexical categories and in assigning adjectives to a lexical category relates in significant ways to the structural variation that is exhibited among the languages of the world. Crosslinguistically adjectives exhibit extraordinary variety, in some languages showing similarities to nouns, in others to verbs and in still others to both nouns and verbs. As a result, within typological linguistics, the claim has been made that some languages have no adjective class at all (e.g. Dixon 1982:2). However, more recent linguistic research, from both the typological perspective (Dixon 2005) and the generative perspective (Baker 2003), has provided compelling evidence that the adjective is a universal word class among the world's languages.

Furthermore, the debate concerning the status of the adjective is mirrored by the broader debate within contemporary linguistics concerning how the issue of grammatical categorisation ought to be approached (for an overview cf. Ansaldo, Don \& Pfau 2008; Libert 2011; Miller-Naudé \& Naudé forthcoming). In generative grammar categorisation is part of universal grammar and each item in the mental lexicon is identified as a member of a particular grammatical category (Chung 2012; Newmeyer 2007; Radford 2004). By contrast, in cognitive linguistics categorisation, namely the ability to judge that a particular thing is or is not an instance of a particular category, is an essential part of cognition (Bybee 2010; Croft 2005). Categories in cognitive linguistics are language specific and category membership is based on prototypicality rather than essential features (Taylor 2003:343). Linguistic typology provides another vantage point for considering categorisation, since typologists use either semantic relations or functions in their work of comparing linguistic structures across languages (Anward, Moravcsik \& Stassen 1997; Haspelmath 2010; 2012).

In this article we re-examine the question of whether or not the adjective is a grammatical category distinct from the noun in biblical Hebrew. We largely omit from the discussion here the related question of the relationship between the adjective and intransitive stative verbs, except when it enhances our argument concerning the differentiation of the adjective from the noun (on stative verbs generally, cf. Cook 2008; Dobbs-Allsopp 2000).

We approach the question of the status of the adjective as a grammatical category by examining the syntax of adjectives and nouns in biblical Hebrew. We demonstrate that the morphological evidence, which has been widely used by Semitists to argue against a differentiation of nouns and adjectives as lexical categories, should be seen as superficial rather than determinative. We then use syntactic evidence to argue that the adjective and the noun are distinct lexical categories.

The linguistic theory utilised in this article is that of Baker (2003) who has provided a compelling theory of lexical categories within the Chomskyian generative tradition, utilising specifically the Principles and Parameters framework. ${ }^{1}$ Baker argues that there are three lexical categories within languages, viz. verb, noun and adjective, and these three categories can be universally distinguished cross-linguistically on the basis of syntactic features. Lexical categories are thus part of universal grammar (i.e. the innate language facility of humans). It is important to note that the syntactic basis of lexical categories in Baker's theory is primary, but the syntactic features project into the morphology and semantics 1.The work of Abney 1987 on adjectival modification is also very important, but will not be considered here. 
of languages because of their inherent interrelatedness (2003:301-302). The approach of this study thus stands in stark contrast to current fashion within some quarters of biblical Hebrew which take a cognitive linguistic approach. In cognitive linguistics lexical categories are primarily semantic in nature. Categories are seen as prototypical semantic descriptions with fuzzy edges. There are two serious problems that can be mentioned here. Firstly, by using prototype semantics every example can be provided with a label no matter how marginal or diverse it is. There is therefore virtually no means of falsifying a cognitive linguistic analysis, thus rendering it empirically questionable. Secondly, in relying upon semantics cognitive linguistics requires Hebraists to determine first what a term in question means, which is intimately connected to its lexical category. As an example consider the term $y$, in the following verse:

3. Job 31:29

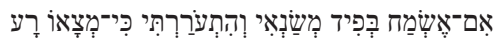

'Did I rejoice over my enemy's misfortune? Did I thrill that (noun? or adjective?) found him?'

Is the term $y$, an adjective or a noun? From a cognitive linguistic perspective it is impossible to decide except in terms of how the term should be translated. But this is also problematic. Does the term רע, refer to 'an evil [person or event]' or does it refer to 'evil' (as an abstract concept)? The former translation implies an adjective; the latter translation implies a noun. The situation is further complicated for English speakers in that evil can be either a noun or an adjective, thus making judgements concerning the meaning of רֵ more opaque. The decision, however, concerning the status of רִ has implications for lexicography-should there be two lemmas indicating homonyms (one an adjective, one a noun), or a single lemma with multiple senses? What is needed is an approach to lexical categorisation that does not depend upon semantics or discourse-pragmatics for its interpretation, but rather upon syntactic facts which are diagnostic of the underlying structure of the sentence within which the item is found. Baker's approach to lexical categories provides the syntactic basis for discriminating categories and it has been empirically tested typologically against a broad spectrum of language families.

The structure of this article is as follows: In the following section, we revisit the morphological evidence concerning nouns and adjectives which has been used to claim that they are indistinct categories. Then we examine the syntactic evidence for distinct categories of noun and adjective in biblical Hebrew. In the final section we present our conclusions.

\section{Morphological evidence}

The morphological similarity of the Hebrew adjective to the noun in terms of inflectional suffixes has been taken by traditional Hebrew grammarians to be evidence for merging the noun and the adjective into one grammatical category. Specifically, the suffixes for the feminine singular, masculine plural and feminine plural are identical. However, as Gai (1995) has demonstrated, this apparent similarity masks deeper differences.

Firstly, nouns are inflected only for singular and plural; gender is specific and inherent to each lexical noun. A noun may thus be masculine or feminine as reflecting natural gender, or it may be grammatically masculine or feminine. The example in (4) is a typical grammatically feminine noun with feminine marking, modified by a feminine adjective:

4. Proverbs 21:14

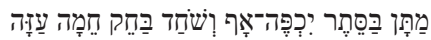

'A gift in secret subdues anger, and a present in the bosom strong rage'.

In the case of feminine nouns whose plurals are formed with a masculine plural suffix, the agreement that the noun selects reflects its intrinsic gender. For example the feminine plural forms of the adjective and of the participial clause that modify the noun in (5) demonstrate that the noun is inherently feminine:

5. Genesis 41:35

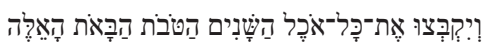

'Let them gather all the food of these good years that are coming ...'

Furthermore, some nouns do not express grammatical gender by morphological means, as illustrated in (6) where the three nouns modified by adjectives all look masculine, but two of them ('hand' and 'arm') are actually feminine, as indicated by the feminine adjectives that modify them:

6. 1 Kings 8:42

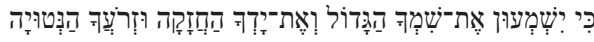

'... for they shall hear about your great name and your mighty hand and your outstretched arm ...'

An adjective is inflected for gender as well as number; its inflectional form relates to agreement with the noun it modifies, not to inherent features within the adjective. In (7) the construct phrase 'man of God' is followed by a masculine singular adjective, which modifies the head noun 'man':

7. 2 Kings $4: 9$

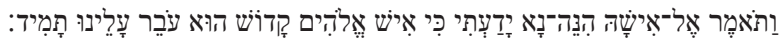

'She said to her husband, "Look, I know that he is a holy man of God, passing by us continually"'.

In (8), the construct phrase 'crown of gold' is modified by a feminine singular adjective, which agrees with the head noun 'crown':

8. Esther 8:15

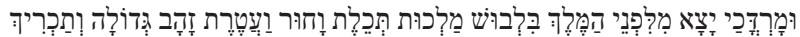

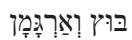

'Mordecai left the king's presence in royal robes of blue and white, with a magnificent crown of gold and a mantle of fine linen and purple ...'

The masculine plural noun in (9) and feminine plural noun in (10) are modified by the masculine plural and feminine plural adjectives, respectively: 


\section{Numbers 5:17}

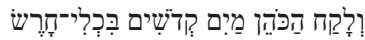

'The priest shall take holy water in an earthen vessel...'

10. Isaiah 32:18

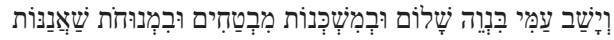

'Then my people shall dwell in peaceful homes and in secure dwellings and in quiet resting-places'.

Secondly, the four inflectional forms of the adjective were productive. This means that every adjective was capable of being inflected as masculine singular, masculine plural, feminine singular and feminine plural in the speech of the ancient Israelites, even though not every adjectival inflection is present in the Hebrew Bible:

11. Deuteronomy 28:38

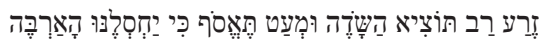

'Though you take much seed out to the field, you shall gather in little, for the locust shall consume it'.

\section{Psalm 110:6}

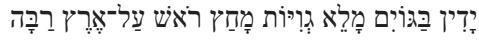

'He will execute judgement among the nations, filling them with corpses; he will shatter chiefs over the wide earth'.

13. Genesis 21:34

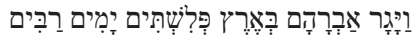

'And Abraham resided in the land of the Philistines many days'.

14. 2 Chronicles 21:3

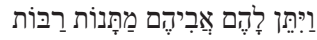

'Their father gave them many gifts ...'

In contrast to the adjective a noun can only be inflected for number. In this respect Hebrew grammars often misrepresent the evidence concerning the noun by indicating that the word סוס 'horse', can be inflected in four ways that mirror adjectival inflection - as masculine singular (ס:0), feminine singular

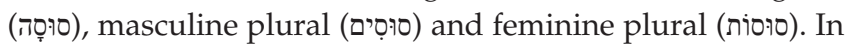
actuality there are two nouns, a masculine noun which refers to a male horse (ס) and a feminine noun which refers to a female horse (סוסָָ). Both nouns may be inflected for number.

Thirdly, although the old dual is fading away in biblical Hebrew, it is still present. But adjectives do not appear in the dual form. A dual noun is modified by a plural adjective:

\section{Isaiah $42: 7$

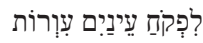 \\ '... to open blind eyes ...'}

On the morphological level, then, nouns and adjectives are distinct although they share some inflectional endings. Their most important difference morphologically relates to gender. For nouns, gender is grammatically inherent in the lexical item and may or may not be expressed by the usual inflectional endings. For adjectives, gender agreement is 'purely grammatical, and is carried out by purely grammatical means for purely grammatical purposes' (Gai 1995:2 cf. also Baker 2003:109).

\section{Syntactic evidence}

The syntactic evidence for the adjective as a grammatical category apart from verbs has not been explored to the same extent as the morphological evidence. However, the syntactic features of Hebrew adjectives leave no doubt that they belong in a separate category from nouns.

\section{Superficial syntactic similarities}

Superficially adjectives in biblical Hebrew share a number of features with nouns. Like nouns they can occur in verbless (or nominal) clauses as the predicate, with or without a finite form of היה as a copula, as illustrated in (16):2

16. Leviticus 11:44

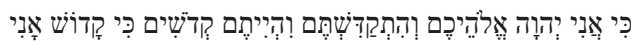

'For I am the LORD your God. Consecrate yourselves, and be holy, for I (am) holy'.

Like nouns, adjectives may appear within construct chains as either the construct or the absolute element, alongside nouns (cf. Joüon \& Muraoka 2009:\$141f). In (17) the adjective forms the first member of the construct chain; the nominal compound serves as the predicate of the verbless clause:

\section{Genesis 24:16

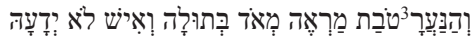 \\ 'The girl was very beautiful (lit. good of appearance), a virgin and no man had known her'.}

In the following section we will present evidence that, in spite of these superficial similarities, the adjective and the noun have distinct syntactic features.

\section{Syntactically distinct features}

Baker (2003:23-94) shows that there are syntactic features which distinguish lexical categories. The verb is the lexical category that takes a specifier and it is the only lexical category that can assign agent and theme roles. In nontechnical terms the verb takes a subject and it assigns to other constituents in the sentence, the syntactic-semantic roles of agent and theme (i.e. subject and object). The noun is the lexical category which has the criterion of identity (2003:95-189). In non-technical terms this means that only the noun can refer and as a result, only the noun can relate to anaphora (pronouns), binding and movement processes. Nouns must be related to argument positions (i.e. nouns function as subjects and objects or complements). The adjective is the lexical category which is neither a verb nor a noun; more precisely, 'adjectives are not inherently predicative (like verbs) or inherently referential (like nouns)' (2003:16). However, the adjective occurs in three distinct syntactic environments in which nouns and verbs cannot occur (2003:191). Firstly, only adjectives are direct attributive

2.Note that neither nouns nor adjectives are inherently predicative; both can, however, form part of a predicate structure (Baker 2003:31).

3.The text critical note of BHS suggests that there is a probable Kethiv-Qere situation in that there is no final / $\mathrm{h} /$ marking the final long /a/ of ? lithough it is not indicated as a Kethiv-Qere in the Masorah. The feminine adjective that follows the noun strongly indicates that the Qere reading is the best, as does the context of noun strongly
the passage. 
modifiers of nouns. Secondly, adjectives can occur as the complements of degree heads (i.e. in English, adjectives can be preceded by so, as, too, how). Thirdly, adjectives can form secondary resultative predicates in some languages (e.g. English They beat the metal flat); however, the adjective in Hebrew does not occur in this environment (2003:226). ${ }^{4}$

We now apply Baker's syntactic features of lexical categories to biblical Hebrew adjectives.

Firstly, cross-linguistically only the adjective (and not the noun) can appear as a direct attributive modifier of a noun and it may do so iteratively (Baker 2003:191, 200; Dixon 2005:15, 22). In biblical Hebrew this is also the case. Only the adjective (not the noun) can function as a direct attributive modifier of a noun, as has already been amply illustrated (see, e.g. [4]-[10] above).

In biblical Hebrew adjectives may also iteratively modify a noun; when more than one adjective modifies the same noun, they are joined with the conjunctive waw:

\section{Exodus 3:8}

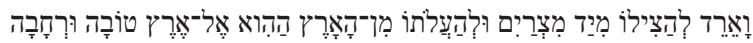

'I have come down to deliver them (lit. him) out of the hand of the Egyptians and to bring them (lit. him) up out of that land to a good, broad land (lit. to a good and broad land) ...'

Note the agreement features between the noun and the attributive adjective which modifies it - the adjectives have the feminine singular suffix to agree with the number and grammatical gender of the noun that they modify. A noun cannot modify another noun in this attributive manner. A different construction in biblical Hebrew can be used, however, for a noun to modify another noun (or nouns), namely the construct relationship, as in (19):

19. Genesis 24:53

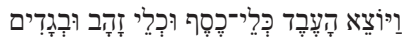

'The servant brought out silver vessels and golden vessels (lit. vessels of silver and vessels of gold) and garments'.

Secondly, adjectives can appear as the complement of 'degree heads' (Baker 2003:191). In English, degree heads include so, too, as and how; contrast the adjectival examples with degree heads in (20a) and the noun examples with degree heads in (20b) (from 2003:212):

(20a) (degee head plus adjective)

'Mary is too intelligent to make such a mistake'.

'Mary is as intelligent as Einstein'.

'Mary is so intelligent that she solved the problem immediately'.

'How intelligent is Mary?'

(20b) (degree head plus noun with and without indefinite article)

* 'Mary is too (a) genius to make such a mistake'.

* 'Mary is as (a) genius as Einstein'.

4.The so-called 'accusative of state' (cf. Waltke \& O'Connor 1990:171-172) does not involve a secondary resultative predicate. For an example of an accusative of state involving an adjective, see Isaiah 20:3.
* 'Mary is so (a) genius that she solved the problem immediately'.

* 'How (a) genius is Mary?'

In biblical Hebrew adjectives can occur as the complement of מָ when it is used as a degree word (cf. Baker 2003:191), often in an exclamative sentence, as illustrated in (21): ${ }^{5}$

21. Psalm 31:20

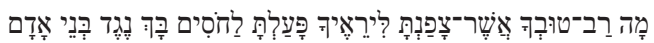

'How great is your goodness which you have in store for those who fear you, (which) you do in the full view of humans for those who take refuge in you'.

Whereas nouns do not occur in this exclamative degree construction, stative verbs may occur:

\section{Psalm 3:2}

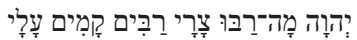

'O LORD, how my foes have become many! Many are those rising up against me'.

Non-stative verbs may also occur in this construction:

23. Job 15:12

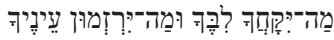

'How your heart has carried you away! How your eyes have failed you!'

The fact that adjectives pattern with verbs, whether stative or non-stative, further demonstrates that adjectives are distinct from nouns.

Thirdly, the noun is always inherently referential (that is, it refers to a specific entity); in technical syntactic terms, only the noun bears a 'referential index' (Baker 2003:95). ${ }^{6}$ In semantic terms, this can be expressed by saying that nouns and only nouns 'satisfy the criteria of identity, whereby they can serve as the standard of sameness' (Baker 2003:95, 116). As a first approximation of these linguistic features, we can say that the noun refers to (or identifies) an item, but an adjective does not. This distinction has significant ramifications for discriminating between nouns and adjectives. However, fully implementing this syntactic test requires that we first consider a particular construction in biblical Hebrew - a definite adjective without an accompanying noun, as illustrated in (24):

\section{Genesis 29:16}

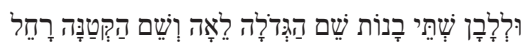

'Now Laban had two daughters. The name of the big (daughter) was Leah and the name of the small (daughter) was Rachel'.

It is clear in this example that the two adjectives preceded by the definite article are attributive adjectives modifying

$5.1 t$ is important to note that nouns may occur as the complement of $i$ but bot when the interrogative word is used as a degree word.

6.One of the anonymous reviewers of this article considers it contradictory that we consider referentiality as a property distinguishing nouns and adjectives in light of consider referentiality as a property distinguishing nouns and adjectives in light of rur contiality is widy reconich referentiality is widely recognised within linguistics as an important aspect of syntax because it relates to syntactic processes such as anaphora, bin As representative of the importance of referentiality to syntax, see Chomsky (1981) and related literature. 
phonologically null (or zero) nouns. ${ }^{7}$ For this reason, the determined adjective appears to be referential in that it refers to a specific big (or small) item in the context, namely a big daughter or a small daughter. However, in fact it is the null noun which is referential and not the adjective. In English one is often used as an anaphoric element in contexts where Hebrew has a null noun-'the name of the big one was Leah and the name of the small one was Rachel'.

A similar example involving an antecedent of the null noun within the preceding context is found in (25):

\section{Numbers $16: 7$}

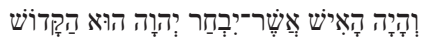

'... and the man $_{i}$ whom the LORD chooses he $\mathrm{i}_{\mathrm{i}}$ shall be the holy $\left(\right.$ man $_{i}$ or one $)$...'

The adjective with a definite article has a null noun referring to its antecedent 'man'.

In some cases of a determined adjective without an accompanying noun, the referent of the null noun cannot be recovered from the immediate syntactic context (in other words there is no syntactic antecedent for it) and must be inferred from the context. In biblical Hebrew this is especially the case in adjectives that describe an attribute of persons (whether human or divine), as illustrated in (26):

26. Job 15:15

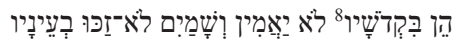

'Behold, he puts no trust in his holy (ones), and the heavens are not pure in his sight';

In this example the adjective modifies a null noun and the noun phrase as a whole is possessive: 'his holy (ones)'. The identity of the holy ones must be inferred interpretatively (or in linguistic terms, pragmatically) from the context; there is no syntactic antecedent of the null noun which the adjective modifies. It is, however, quite possible to determine the referent on the basis of the 'heavens' in the accompanying poetic line; 'his holy ones' are heavenly beings.

Another example of an interpretively (or, pragmatically) identified null noun is found in (27):

\section{Psalm 34:10}

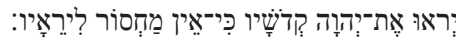

'Fear the LORD, O his holy (ones), for there is no lack for those who fear him!'

The adjective is definite by virtue of its pronominal suffix and the null noun must be inferred as 'people' or 'ones'. The referentiality of the expression is clear, because on the one hand it is used as a vocative to address the congregation,

\footnotetext{
7.Other phonologically null elements have been identified previously in biblical Hebrew and Aramaic, including null subject constituents (Naudé 1991. 1994. 1996 ; 1999), null noun phrases after the movement of noun phrases due to topicalisation 199), null or extraposition (Holmstedt 2014; Naudé 190; 1991; 1994), null copulas in after ellipsis (Miller 2007), null negative markers after ellipsis (Miller 2005), null relative markers and null heads of relative clauses (Holmstedt 2013; 2016).
}

8.Reading with the Qere as opposed to the Ketiv. and on the other hand the following poetic line mentions 'those who fear him', which further describes 'his holy (ones or people)'.

In examples with an antecedent of the null noun, as in (24) and (25), and in examples with a pragmatically inferred antecedent, as in (26) and (27), the construction is identical. The adjective is attributive and modifies the null noun. It is the null noun which is referential and which meets the criterion of identity, not the adjective. Stated differently, when an adjective occurs with the definite article (or in another definite construction in biblical Hebrew), it is necessary either to reconstruct a null noun from the previous discourse context or to use a generic common noun such as people or one (Baker 2003:123).

Indefinite adjectives may also modify a null noun, as in the following example:

28. Leviticus 27:10

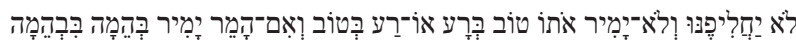

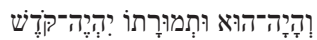

'He shall not exchange it or make a substitute for it, a good (one) with a bad (one), or a bad (one) with a good (one); and if he does in fact substitute one animal for another animal, then both it and its substitute shall be holy'.

In this example the bare adjectives must be understood as modifying null nouns whose antecedents are in the syntactic context.

Recognising the presence of null nouns with attributive adjectives assists in the interpretation of passages such as the following:

29. Genesis 16:6

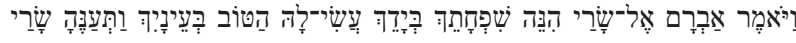

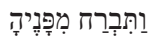

'Abram said to Sarai, "Look, your maid is in your control. Do to her the good (thing) (lit. the good) in your eyes". Then Sarai treated her harshly and she fled from her'.

In this example Abram instructs Sarai to take action in accordance with what is good in her opinion. The adjective is not referential but the null noun is; the implication is that Abram is aware of what Sarai would do. ${ }^{9}$ The use of can be contrasted with the construction in which the adjective is a predicative adjective:

\section{2 Samuel 19:38}

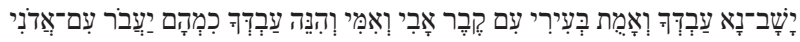

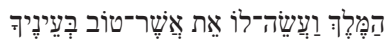

'Please let your servant return, that I may die in my own city near the grave of my father and my mother. But here is your servant Chimham. Let him go over with my lord the king, and do for him what (lit. the thing which [is] good) in your eyes'.

9.Other similar examples of בivi include: Genesis 16:6; $20: 15$; Numbers $10: 32$ Deuteronomy 12:28; 26:11; Judges 10:15; 19:24; 1 Samuel 1:23; 3:18; 11:10; $14: 36$, Deuteronomy 12:28; $26: 11$; Judges $10: 15 ; 19: 24 ; 1$ Samuel $1: 23 ; 3: 18 ; 11: 10 ; 14: 36$,
40; $15: 9 ; 2$ Samuel 10:12; $14: 17 ; 19: 19,28,39 ; 24: 22 ; 2$ Kings $10: 5 ; 1$ Chronicles 19:13; 21:23; 2 Chronicles 14:1; 19:11; 31:20; Job 2:10; Psalm 85:13; Jeremiah 5:25. 
In (30), the object of the verb is now introduced with the definite object marker - - and is followed by a phonologically null noun which is modified by a relative clause consisting of a reduced verbless clause with a predicate adjective.

We can further contrast the referentiality of definite nouns and definite adjectives in the following example:

\section{Deuteronomy 30:15}

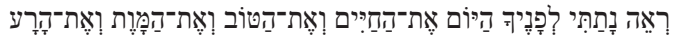

'See, I set before you today life and the good (thing), and death and the bad (thing)'.

'Life' and 'death' are referential definite nouns; the definite adjectives 'the good' and 'the bad' are not referential nouns in and of themselves but the null nouns must be inferred from the context. Some translations, however, utilise referential nouns such as 'prosperity' and 'adversity', respectively, for these terms (see, e.g. the NJPS, NRSV, NAB).

With this understanding concerning definite adjectives and phonologically null nouns, we can explore three ways in which the referentiality and non-referentiality of adjectives have syntactic ramifications in biblical Hebrew: adjectives cannot serve as the antecedents of pronouns (as nouns do), adjectives are not modified by relative clauses (as nouns are), and adjectives cannot serve as arguments of verbs (as nouns do).

Firstly, only a noun can serve as the antecedent of an anaphoric pronoun or a reflexive pronoun (Baker 2003:126-27), as illustrated for English in (32): ${ }^{10}$

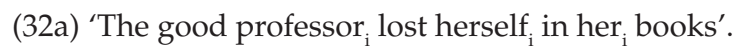

(32b) 'Choose whether you want the good book or the bad one'.

(32c) * 'Choose whether you want the good $_{\mathrm{i}}$ book or the $\varnothing_{\mathrm{i}}$ journal (with the meaning the good journal)'.

In (32a) the antecedent of the anaphoric pronoun her and the reflexive pronoun herself can only be the noun professor and not the adjective good. In (32b) the antecedent of one is the noun book; but in (32c) any attempt to use good as a modifier of journal is not grammatical. The same is true in Hebrew. In (33) the antecedent of the pronoun suffixed to the preposition הָאָדָם is and not רָז

\section{Ecclesiastes 8:6}

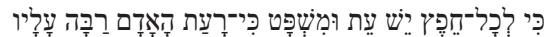

'For there is a time for every experience, including the doom; for a man's calamity (lit. the evil of the man $n_{\mathrm{i}}$ ) overwhelms him.'.

In (34) the antecedent of the pronominal suffixes on the verbs

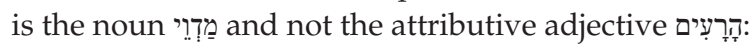

34. Deuteronomy 7:15

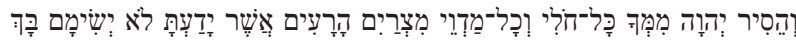

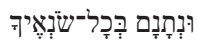

10.In accordance with linguistic practice the subscripted letter ' $i$ ' in these examples indicates co-referential items, and the asterisked example indicates an ungrammatical sentence.
'The LORD will ward off from you every sickness. And all the terrible diseases ${ }_{\mathrm{i}}$ of Egypt which you know, he will not bring them $\mathrm{i}_{\mathrm{i}}$ upon you, but he will give them $\mathrm{i}_{\mathrm{i}}$ upon all of your enemies'.

In (35) the antecedent of the pronominal suffix on the quantifier i $_{\text {is }}$ the null noun that the adjective modifies rather than the adjective itself:

\section{Jeremiah $6: 13$}

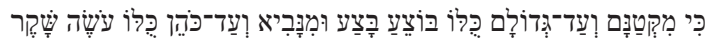

'For from their small (one $e_{i}$ ) to their great (one), each one $e_{i}$ (lit. all of him) is greedy for unjust gain; and from prophet to priest, each one is doing deceit'.

Secondly, nouns can be modified by relative clauses (and other syntactic attributive modifications) but adjectives cannot (Dixon 2005:23), as illustrated in (36):

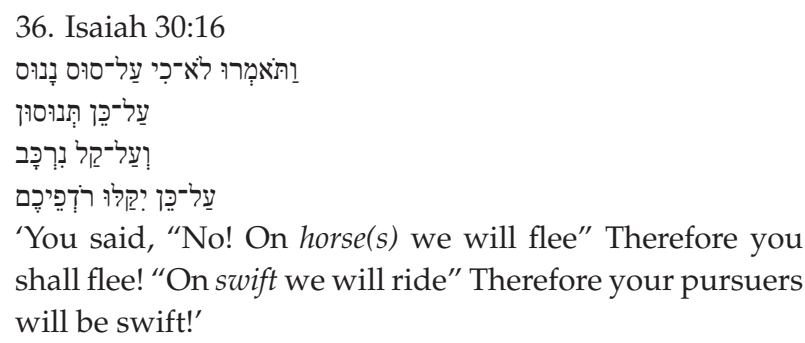

In this example the adjective קֵ occurs without a noun; the noun it modifies is 0 , which occurs in the first line but is elided in the third line for poetic effect.

Thirdly, nouns (but not adjectives) may serve as arguments (i.e. subjects and objects) in clauses (Baker 2003:142); this follows from the fact that nouns have referential indices but adjectives do not. In English this difference is most apparent in the contrast between a bare noun (but not a bare adjective) serving as the subject of a sentence because English allows only null nouns of plural attributive adjectives (e.g. the poor; examples from Baker 2003:18):

(37a) 'Water frightens me'.

(37b) *`Poor frightens me (contrast Poverty frightens me)'.

A bare noun (i.e. a noun without a definite article or adjectival modification) is the subject of a verbal clause in biblical Hebrew in (38):

\section{Exodus $15: 8$}

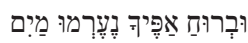

'At the blast of your nostrils, (the) waters piled up'.

Similarly, a bare noun can serve as the subject in a verbless clause:

\section{Genesis 8:9}

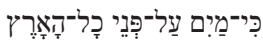

'... for (the) waters (were) upon the face of all the earth'.

In biblical Hebrew bare adjectives can always be understood as attributively modifying a null noun. As a result, in the few 
cases where a bare adjective apparently functions as the subject or object of a sentence, a phonologically null noun must be understood:

40. Job 30:26

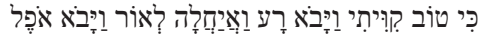

'I looked for a good (thing) but an evil (thing) came; and I hoped for light but darkness came'.

Both the object of the first clause and the subject of the second clause are indefinite adjectives which modify indefinite null nouns (see also the examples of indefinite subjects and objects in [28] above).

We are now ready to re-examine example (3), repeated here:

3. Job 31:29

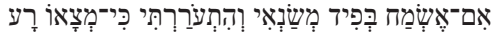

'Did I rejoice over my enemy's misfortune? Did I thrill that רุ (noun? or adjective?) found him?'

In general the word רָ in the Hebrew Bible is undoubtedly in the first instance an adjective. But because it also occurs in contexts where it is not a predicate adjective and it does not modify an overt noun, the dictionaries also list it as having a secondary 'substantival' use (s.v. רָ in HALOT), or as having a homonym which is a noun (s.v. רָ II. in BDB). However, based on the analysis provided above both HALOT and BDB approach the lemmatisation of רָ incorrectly - the word does not have a secondary 'substantival' use (or sense), nor does it have a homonym. Instead, it is best to understand רָ as an adjective, which may modify a phonologically null noun. In the context of the verse this indefinite null noun is referentially identical to (or, in light of the poetic parallelism, a synonym of) the noun פִיד in the previous clause (and poetic line).

\section{Conclusion}

This study has drawn upon linguistic theory and crosslinguistic typology to provide a new interpretation of the morphological data regarding adjectives in biblical Hebrew. It has also extended the analysis of adjectives by considering the ways in which the syntax of adjectives is superficially similar to that of nouns and the ways in which the syntax of adjectives is distinct from that of nouns.

The adjective in biblical Hebrew shares many superficial morphological features with nouns, especially with regard to inflectional suffixes and with regard to the fact that both adjectives and nouns can form the predicate of a verbless clause or an existential clause with היה However, adjectives differ from nouns in morphologically and syntactically significant ways: they do not have inherent gender (their gender and number is a result only of agreement with the noun they modify); they do not have a dual inflectional form; only the adjective can function as a direct attributive of the noun; only the adjective can serve as the complement of as a degree word; the adjective is not inherently referential (whereas the noun is referential); and an adjective cannot serve as the antecedent of an anaphoric pronoun or a reflexive pronoun (but nouns can).

Baker (2003) has identified syntactic features which universally differentiate three lexical classes - verbs, nouns and adjectives. Verbs are inherently predicates, nouns are inherently referential, and adjectives are neither inherently predicates nor inherently referential. In examining the biblical Hebrew data in light of these syntactic features we discovered that they assist us in differentiating nouns and adjectives, provided that phonologically null nouns are recognised. Furthermore these syntactic features help us to understand some of the distinctive features of biblical Hebrew adjectives in a coherent way. Firstly, the morphological characteristics that distinguish nouns and adjectives are directly related to the referentiality of the noun and the non-referentiality of the adjective. Because adjectives do not refer, they do not inherently have number or gender; instead these features are present only by virtue of agreement with a noun, and as Baker noted, one of the distinctive functions of adjectives is to serve as the direct attributive modifier of nouns. Secondly, we noted that both nouns and adjectives may function as the predicate of verbless sentences, but we described this as a superficial feature and not a feature that should be understood as advocating for a combined lexical category. The fact that both nouns and verbs can serve as verbless predicates relates to Baker's observation that only verbs inherently predicate. Nouns and verbs thus share a syntactic construction by virtue of the fact that both are not verbs and not because they are of the same lexical category. Thirdly, the tendency for Hebraists to join adjectives with nouns under the rubric 'substantives', is a result of the fact that Hebrew exhibits phonologically null nouns. An adjective which attributively modifies a phonologically null noun seems to be 'substantival', when in fact it is not - such an adjective is simply attributive to the null noun.

We conclude that the noun and the adjective are distinct lexical categories in biblical Hebrew and they should not be subsumed under the category of 'substantive' or 'nomen'. An examination of syntactic features provides principled means for differentiating the two within the biblical text.

\section{Acknowledgements Competing interests}

The authors declare that they have no financial or personal relationships which may have inappropriately influenced them in writing this article.

\section{Authors' contributions}

C.L.M.N. and J.N. jointly conceptualised the research and analysed the data. C.L.M.N. edited the article.

\section{References}

Abney, S., 1987, 'The English noun phrase in its sentential aspect', PhD dissertation, Department of Linguistics, MIT, Cambridge, MA.

Andersen, F.I. \& Forbes, A.D., 2012, Biblical Hebrew grammar visualized, Eisenbrauns, Winona Lake, IN. 
Ansaldo, U., Don, J. \& Pfau, R., 2008, 'Parts of speech: Particulars, universals and theoretical constructs', Studies in Language 32(3), 505-508.http://dx.doi.org/ 10.1075/sl.32.3.02ans

Anward, J., Moravcsik, E. \& Stassen, L., 1997, 'Parts of speech: A challenge for typology', Linguistic Typology 1(2), 167-184. http://dx.doi.org/10.1515/lity.1997. 1.2.167

Baker, M.C., 2003, Lexical categories: Verbs, nouns, adjectives, Cambridge University Press, Cambridge.

Brown, F., Driver, S.R. \& Briggs, C.A., 1906, A Hebrew and English lexicon of the Old Testament, Clarendon, Oxford. (Ábbreviated BDB).

Bybee, J., 2010, Language, usage and cognition, Cambridge University Press, Cambridge.

Chomsky, N., 1981, Lectures on government and binding, Foris Publications, Dordrecht. (Studies in Generative Grammar 9).

Chung, S., 2012, 'Are lexical categories universal? The view from Chamorro', Theoretical Linguistics 38(102), 1-56.http://dx.doi.org/10.1515/tl-2012-0001

Cook, J.A., 2008, 'The Hebrew participle and stative in typological perspective', Journa of Northwest Semitic Languages 34(1), 1-9.

Croft, W., 1991, Syntactic categories and grammatical relations, University of Chicago Press, Chicago.

Croft, W., 2005, 'Word classes, parts of speech and syntactic argumentation', Linguistic Typology 9(3), 431-441.

Dixon, R.M.S., 1982, Where have all the adjectives gone? And other essays in syntax and semantics, Mouton, Berlin.

Dixon, R.M.S., 2005, 'Adjective classes in cross-linguistic perspective', in R.M.S. Dixon \& A.K. Aikhenwald (eds.), Adjective classes: A cross-linguistic typology, pp. 1-49, Oxford University Press, Oxford.

Dobbs-Allsopp, F.W., 2000, 'Biblical Hebrew statives and situation aspect', Journal of Semitic Studies 45(1), 21-53.http://dx.doi.org/10.1093/jss/45.1.21

Gai, A., 1995, 'The category "adjective" in Semitic languages', Journal of Semitic Studies 40(1), 1-9.http://dx.doi.org/10.1093/jss/XL.1.1

Gesenius, W., Kautzsch, E. \& Cowley, A.E., 1910, Gesenius' Hebrew grammar, 2nd English edn., Clarendon, Oxford.

Givón, T., 1984, Syntax: A functional-typological introduction, Benjamins, Amsterdam.

Haspelmath, M., 2010, 'Comparative concepts and descriptive categories in crosslinguistic studies', Language 86(3), 663-687.http://dx.doi.org/10.1353/lan.2010.0021

Haspelmath, M., 2012, 'Escaping ethnocentrism in the study of word-class universals', Theoretical Linguistics 38(1-2), 91-102.http://dx.doi.org/10.1515/tl-2012-0004

Hengeveld, K., 1992, 'Parts of speech', in M. Fortescue, P. Harder \& L. Kristoffersen, Layered structure and reference in a functional perspective, pp. 25-55, Benjamins, Layered structure and reference in a functional perspectiv
Amsterdam. (Pragmatics and Beyond, New Series 23).

Holmstedt, R.D., 2013, 'Relative clause: Biblical Hebrew', in G. Khan (ed.), Encyclopedia of Hebrew Language and Linguistics, vol. 3, pp. 350-337, Brill, Leiden.

Holmstedt, R.D., 2014, 'Critical at the margins: Edge constituents in biblical Hebrew', Kleine Untersuchungen zur Sprache des Alten Testaments und seiner Umwelt 17, 109-156.

Holmstedt, R.D., 2016, The relative clause in biblical Hebrew, Eisenbrauns, Winona Lake, IN. (Linguistic Studies in Ancient West Semitic 10).

Hopper, P. \& Thompson, S., 1984, 'The discourse basis for lexical categories in universal grammar', Language 60(4), 703-752. http://dx.doi.org/10.1353/lan.1984.0020
Jackendoff, R., 1977, X-Bar Syntax, MIT Press, Cambridge, MA.

Joüon, P. \& Muraoka, T., 2009, A grammar of biblical Hebrew, 2nd edn., with corrections, Gregorian Biblical Press, Rome.

Koehler, L. \& Baumgartner, W., 2001, The Hebrew and Aramaic Lexicon of the Old Testament, rev. by W. Baumgartner \& J.J. Stamm, transl. M.E.J. Richardson, Brill, Leiden. (Abbreviated HALOT).

Libert, A.R., 2011, 'Word classes (parts of speech)', in P.C. Hogan (ed.), The Cambridge Encyclopedia of Language Sciences, pp. 915-917, Cambridge University Press, Cambridge.

Miller, C.L., 2005, 'Ellipsis involving negation in biblical poetry', in R.L. Troxel, K.G. Friebel \& D.R. Magary (eds.), Seeking out the wisdom of the Ancients: Essays offered to honor Michael V. Fox on the occasion of his sixty-fifth birthday, pp. 37-52, Eisenbrauns, Winona Lake, IN.

Miller, C.L., 2007, 'Constraints on ellipsis in biblical Hebrew', in Studies in comparative Semitic and Afroasiatic linguistics presented to Gene B. Gragg, pp. 165-180, The Oriental Institute of the University of Chicago, Chicago. (Studies in Ancient Oriental Civilization 60).

Miller-Naudé, C.L. \& Naudé, J.A., forthcoming, 'Word classes, linguistic theory, typology and universals: A re-examination of grammatical categorisation in biblical Hebrew', in K. Dyer, T. Li \& A. Lyavdansky (eds.), From ancient manuscripts to modern dictionaries: Select studies in Aramaic, Hebrew, and Greek, Perspectives on Linguistics and Ancient Languages, Gorgias.

Naudé, J.A., 1990, 'A syntactic analysis of dislocations in biblical Hebrew', Journal of Northwest Semitic Languages 16, 115-130.

Naudé, J.A., 1991, 'Qumran Hebrew as a null subject language', South African Journa of Linguistics 9, 119-125.http://dx.doi.org/10.1080/10118063.1991.9724303

Naudé, J.A., 1994, 'The asymmetry of subject pronouns and subject nouns in Qumran Hebrew and cognates', Journal of Northwest Semitic Languages 20, 139-163.

Naudé, J.A., 1996, 'Independent personal pronouns in Qumran Hebrew syntax', DLitt thesis, Department of Near Eastern Studies, University of the Free State, Bloemfontein.

Naudé, J.A., 1999, 'Syntactic aspects of coordinate subjects with independent personal pronouns', Journal of Northwest Semitic Languages 25(2), 75-99.

Naudé, J.A., 2002, 'The third person pronoun in tripartite verbless clauses of Qumran Hebrew', in H.J. Simon \& H. Wiese (eds.), Pronouns: Representation and grammar, pp. 161-182, Benjamins, Amsterdam.

Newmeyer, F.J., 2007, 'Linguistic typology requires crosslinguistic formal categories', Linguistic Typology 11, 133-157.http://dx.doi.org/10.1515/LINGTY.2007.012

Radford, A., 2004, Minimalist syntax: Exploring the structure of English, Cambridge University Press, Cambridge.

Richter, W., 1978, Grundlagen einer althebräischen Grammatik, TI. 1, Das Wort (Morphologie), EOS Verlag, St. Ottilien.

Richter, W., 1979, Grundlagen einer althebräischen Grammatik, TI. 2, Die Wortfügung (Morphosyntax), EOS Verlag, St. Ottilien.

Richter, W., 1980, Grundlagen einer althebräischen Grammatik, TI. 3, Der Satz (Satztheorie), EOS Verlag, St. Ottilien.

Taylor, J.R., 2003, Cognitive grammar, Oxford University Press, Oxford. (Oxford Textbooks in Linguistics).

Waltke, B.K. \& O'Connor, M., 1990, Introduction to biblical Hebrew syntax, Eisenbrauns, Winona Lake, IN. 